\title{
Role of Libraries in conflict and peace process in Sri
}

\section{Lanka}

\section{Author}

\section{Maheswaran, $\mathbf{R}$}

MLS (Colombo), Dip. In Hockey Coaching (Singapore)

Senior Asst. Librarian, Tamil Division, Main Library

University of Peradeniya. Sri Lanka

\section{Contact Details}

Tel :

00-94-81-2388678

Fax:

$00-94-81-2392470$

\section{Abstract}

There has been an ethnic conflict between the two major communities in Sri Lanka from late 1970 's. It is a struggle between the Sinhala majority and the Tamil minority about the political and cultural control of a given territory greatly aggravated by the Liberation tigers of Tamil Eelam. Although it is said the basis of the crisis is supported by an overly narrow view 
of the possible relation between ethnicity and religion, there is the view that in case of Sri Lanka, important historical realities are either ignored or distorted. The war situation cause a massive economic burden to the country in many ways including lowering of standards of livings and causing migration of skilled labour out of the country. There were various political attempts from the 1960's, with and without third party mediation, to resolve the conflict but all begun in 2002. It is at crossroads and offers a unique opportunity to find an amicable solution to the ethnic crisis in Sri Lanka. The education policy in the country and religious dignities in the country are expected to play important roles in the peace process by changing the attitude of people of the nation. There are many records from earliest time to the present day that document the fact that the Libraries and information centers were destroyed and affected during conflicts or war, in locally and internationally. Although there is long a history of threats to libraries, they can play an important role in creating ethnic harmony. Libraries are expected to change attitude of the civil society, which is a stakeholder in the peace process. The libraries - school libraries, public libraries, university libraries and national library can effectively bring about the attitudinal changes in the minds of the nation. Libraries should work with great effort to create the civil society, which with sustained public support will formulate ways and means to create the ethnic harmony. 
'Khilji' annihilated Nalanda University the famous Buddhist seat of learning in North India with a three-block library, one block was nine story's high". Piyadasa (1985)

The history of Sinhala literature too recorded destruction of libraries in the Anuradhapura - Polonnaruwa, Dambadeniya period( $9^{\text {th }}-13^{\text {th }}$

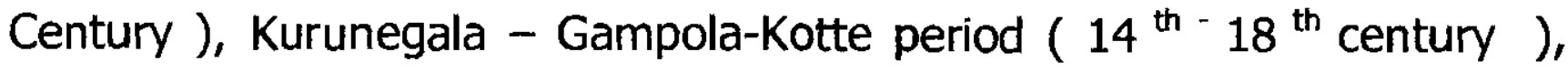
Sitawake-Kandy period $\left(17^{\text {th }}-18^{\text {th }}\right)$.

In the recent past, after the District Council election in Jaffna on 1st June 1981 with the collection of nearly 97,000 books, the Jaffna Public Library was consigned to flames. The burning of the Jaffna Public Library with several rare historical collections was a great loss not only to the people of Jaffna, but also to the entire nation.

The Sri Dalada Maligawa in Kandy, the temple, which houses the Sacred Tooth Relic of the Lord Buddha, is possibly the most sacred Buddhists Shrine in the world. It is venerated not only by Buddhist in Sri Lanka, but also by Buddhist all over the world. It was bombed on $25^{\text {th }}$ January 1998 by suicide cadres. It also housed many sacred books and palm-leaf manuscripts. After this incidence, there was a rumor that the Tiger cadres were going to attack the University Of Peradeniya Library. The University Administration took various security steps. They hired a retired senior Superintendent of Police as a security adviser. Railings (rail of Iron) were used to fence the library building to prevent any vehicles that may be carrying explosives from entering the library premises. At the entrance to the Library, Metal detector was fixed. Fire extinguishing training was given to all library staff. Vigilance committees were formed. The Vigilance committee worked round the clock. Civil security service 


\section{Key Words: Peace Process, Role of Libraries, Sri Lanka, Tamil, \\ Sinhala}

\section{Introduction}

The ethnic conflict, which has been prevailing in Sri Lanka from the late seventies, contains political and territorial dimensions and the micro dimension are in social, Economic, cultural, and governance sectors. Both are closely intertwining with the party political conflict in the south and the Tamil-Muslim relationships in the Northeast. All political attempts to solve the underlying problem became- fruitless. Some experts think that the change of attitude in the minds of the people and the politicians of both parties can be the only way to solve the problem. Churches, temples, mosques, Buddhist temples and their religious dignitaries will have to play important role in this context. Schools too will have assumed responsibility in fostering ethnic amenity in the hearts and minds of the student population of the country.

\section{Libraries in conflict situations}

Alexandria, the capital of Egypt from its founding by Alexander the Great, established in 332 B.C. was a center of learning and the focal point of Greek scholarship: As a result, the great research institute museum and libraries were started. The reputed Alexandrian library, which contained 500,000 volumes, was destroyed during the civil war of the $3^{\text {rd }}$ Century AD: Christians burned a subsidiary library in AD 391 . Encyclopedia Britannica (1973)

"The last of recorded destruction of a library in the subcontinent was towards the end of the $12^{\text {th }}$ century. When a Central Asian Horde under 
men were also posted around the library. This was the situation in Peradeniya, in this period, before peace negotiation. If a Tamil library staff member happened to be absent, all other staff and employees in the library worked with fear; some staff went on leave. All the staff worked under mental stress, expecting a suicide attack similar to 'Maligawa' attack. This was the situation in libraries locally as they have been internationally during conflicts.

Although there is a long history of threats to libraries and various information centers during wars and conflicts, the libraries and information centers can play an important role in ethnic harmony. This is an easy way to understanding the nature of the country's complex political crisis and explaining as best as possible, the various attempts at resolving the conflict and what was done right but which, latter however, proved to be inadequate to meet the mounting pressure of the persisting conflict. It also has been dealt with how the library could act towards the ethnic harmony in Sri Lanka.

\section{Conflict in Sri Lanka}

There is a struggle between the Sinhalese and Tamils about the political and cultural control of a given territory. The basic problem is that they are inhibited by an overly narrow view of the possible relations between ethnicity and religion, a view that in the case of Sri Lanka, ignores or distorts important historical realities. "Ethnic" and "ethnicity" means people, race, or tribe, but in two quite distinct ways. The Oxford English Dictionary (1986)

Sri Lanka's Long Civil war has extracted an enormous economic cost in terms of lost productivity, lost investment, and mis-allocated resources, 
resulting in a lower standard of living that would have not occurred in a peacetime setting. Although the ethnic conflict had continued for several years, it became a burden on the economy after civil war. The number of investment and production opportunities forgone could be considered the primary cost of the war. Damage to the physical and social infrastructure would be reflected in loss of production in various sectors of the economy, loss due to non-productivity, disruptions of normal work in areas affected by the war, a sense of insecurity and migration of skilled labor out of the country. There is another form of economic loss to the nation: damage of private property, destruction of government properties and infrastructure of the nation such as bridges, roads and railway lines.

This damage to the country was further compounded by the present policy on education implemented by the government of Sri Lanka, which fosters communal divisions in society. In late 1950's all schools were in effect "Communalized". Connections can be traced between changes in the education system and the worsening of ethnic tensions. One factor for the ethnic tension was change in the medium of instruction. It also resulted in the reduction of bonds of friendship between Sinhalese and Tamil. This situation was aggravated and magnified during the government's university admission policy introduced in the 1970's. The distributions of elementary facilities among the schools and universities, was neither equal nor fair, and thus some ethnic groups and region suffered deprivation.

\section{Peace Process}

There were discussions between the leaders of one conflicting party and the leaders of ruling parties to ease the situation from early sixties. Determined and detectable efforts to alter this troubling situation, could 
constitute an important first step toward establishing the kind of commitment to equal rights that is so obviously required to overcome the legacy of ethno-religious nationalism in Sri Lanka. Increase of communication and understanding between conflicting parties was a step toward the peace process; there were chances created to promote greater tolerance and acceptance of diversity. There must be created ways and means to assist the conflicting parties to identify and share their unmet needs, and generate options for meeting those needs and for the parties to reach to an agreement to meet the basic needs of all of the parties involved in the conflict. The situation must enable conflicting parties to identity threats and fears they each feel and to build empathy and reconciliation away them and also increase knowledge of each other's cultures and increase effective intercultural communication, changing structures of economic redistribution. These steps are expected to improve long-term relationships and attitudes, developing processes for justice, peace, forgiveness, reconciliation and recognition. Social integration of youths can be attempted.

In 1983-1987, there was Indian mediation. During that period the Tamils submitted a draft proposal to accept the Tamils of Sri Lanka as a distinct nationality, identified a Tamil homeland and sought re-guarantee of its territorial integrity, the inalienable right of the self-determination of Tamil nation, the right to full citizenship and other fundamental right of all Tamils. Time to time there were attempts to solve the ethnic conflict prevailing in Sri Lanka. After 1987, several more attempts were initiated under different government of Sri Lanka. The provincial councils were set up in the country in 1988, in view of solving the conflict, but ended in failure. 
In 2002, another fresh peace process was resumed with a cease-fire negotiated with foreign mediation - namely Norway. Resettlement and rehabilitation were started in the North - East. So far, there is no fruitful solution to the ethnic conflict. Political experts believe that there should be actual motivation on the part of the Sri Lankan ruling political party and the opposition parties which representative the majority ethnic group - namely Sinhalese.

All political attempts to solve the underlying problem became fruitless in the end. Some experts think that change of attitude in the minds of the people and the politicians of both parties and the LTTE, only can give a chance problem solving. Churches, Hindu temples, mosques and Buddhist temples and other religious dignitaries will have to play an important role in this context. The clergy, monks and other religious dignities and organization officials are expected to advise, propagate, relevant information and campaign on the importance of peace to the nation, the loss due to the ethnic.conflict, human rights and concept of decentralization, federalism etc to change the attitude of people. The people can be easily reached. All organizations of devotees working towards the furtherance of their beliefs and development of their religious institutions must work together with understanding. The first step in this direction is to ensure that member of the Sanga receive more feedback on the attitude and grievances of the minorities and have the opportunity to enter into a dialogue with them. Such a dialogue is essential for trust building and could well begin by explorations into how to ensure the provision of common basic human needs of all citizens. 


\section{Policy on Education}

Schools also can play an important role in the peace process. The value of education cannot be underestimated in the peace process. Education should emphasized peaceful co-existence of the races. Traditional festivals and customs should be taught at schools. Students need to be introduced to books, relevant to war and peace," living and working together. The school library also must play an important role to encourage pupil in the reading habit, to develop the ability to learn from books without a teacher, to assist the children to enjoy reading and read with discrimination and to make profitable use of leisure time - these type of procedures would make them to obtain information of their own. In addition, the younger generation must obtain information about the basis of the present crisis without any other political, religious and cultural influences, so they can formulate or help to find a resolution to crisis.

The education at the territory level also should not be overlooked. Restoring ethnic harmony depends more on than constitutional and administrative arrangements. It depends on the ability of the educational system to inculcate values suitable for a multiethnic society. Education can promote the ethnic harmony by following the mentioned ways:

- Expected education is in decreasing ethnocentricity and developing more tolerant attitudes.

- Language studies - students can study their mother tongue and the other languages I-e English and either Tamil or Sinhala. This will 
create a foundation to understand the three languages and through the languages, the culture of others.

These procedures make the future generation to understand the actual situation and the facts behind the ethnic conflict to find amicable and acceptable solution.

\section{Role of Libraries in the peace process}

Libraries can play an important role in the transmission of knowledge that is the vital fact of the education system. Integration of the library with community, state, regional and national library resources, act as an establish information focal centers for the needy personals towards the ethnic harmony. The libraries as information centers could organize and disseminate the data and information spawned by wide spectrum of activities - a productive asset in itself with potential as yet untapped fully.

Provision of general information - The library must collect and display materials that could provide the actual basis of the conflict, the pattern of the conflict, effects of the conflict, the peace process, intension and fears of parties involved. These aspect covered are generally governed by the consideration of relevance to the national context and should include data of research that has been carried out by indigenous scholars about the ethnic conflict and the intention and motivations of mediation.

Provision of specific information - Library as an information center, has to have specific information about the actual basis of the crisis, what 
are the facts relevant to both parties a to struggle, the motivations of foreign intervention. It should have documents explaining the basis of the resolutions, the basis of the claim of one party, materials on decentralization, the principle of subsidiary governments, the relations with federalism.

Library Exhibitions - There must be several library exhibitions explaining the conflicts, and the peace process. The library staff and the government and non-governmental officials are expected to hold library exhibitions of the materials that will explain the conflict and the peace process. What was the wrong with the past attempts of peace process? What are the remedies to resume the negotiation process? The exhibition would also explain the pros and cons of the recent and past peace processes quoting good examples from other countries.

Displày of current Publications - The library has to have current publications about the conflict and the peace process, the basis of the claim or demands, the research publications on the basis of the claim or demand of traditional homeland which was submitted at Thimpu negotiation in 1985, sustainable solution of the crisis - federalism, decentralization as resolution for ethnic conflict etc.

Maintaining clippings - There should be paper clipping about the conflict and peace process, role of religious dignitaries in the peace process, the mistakes committed in past peace attempts, the basis of failure in negotiating process to find amicable solution with foreign intervention, etc. The libraries should not fail to collect and maintain clipping from magazines, pamphlets, etc. about the above mentioned items and any related facts to the peace process and the ethnic conflict. 
Translation of materials and other services - The library must have books and materials in different languages and translated copies of the originals: Eg; Tamil material into Sinhala and vise versa, as many as the library could afford to possess. These translated materials could help to induce understanding of the culture of each other's community. Maintenance of vertical files, collecting and maintaining pamphlets, prospectuses, reports, etc. about the war situation and the present and past peace making processes is also vital.

Library Publications - The library can also contribute by preparing handbooks of library publications, library bibliographies, and collection indexes on conflicts and peace process. Libraries, with the assistance of intellectuals could formulate, organize, and conduct various workshops and dialogue models that have been developed with the help of the experts to assist in the resolution of conflicts, develop problem solving workshops based on basic human needs and right theory, and interacting workshops based on socio-psychological approaches.

The present library system in Sri Lanka can be divided into four categories:

- School library

- Public library

- University library

- National library.

The library system can work with the readers of the respective category to further the peace process in the following ways: 


\section{School libraries}

School libraries are expected to work with the children and youngsters. Audio-visual aids about the peace process and ethnic harmony are very important and fascinating from the children's point of view. Reference books that deal with various cultures and religious activities should contain sufficient illustrations.

Readers' advisory service should be formed and it should guide the students about background to ethnic grouping and information about the various groups.

The library must pay more attention to acquisition of translated literatures. - Sinhala

Literatures translated into Tamil and vise versa. Library can display posters about religious activities and cultural importance and organize wall magazine, which can display students' creativity on peace and ethnic harmony. Art exhibition or photo exhibition relevant to the peace and ethnic harmony would also be advisable. The newly appointed school librarian should also be trained to cater this purpose.

\section{Public Libraries}

Public libraries are expected to 'educate' children and adults. As such it can function as School libraries and provide more mature reader with reference service and good lending service. It can display posters and hold books exhibition, photo exhibition and art exhibition about basic 
human rights, basis of ethnic conflict and the basis of finding a resolution to the crisis. It must explain how similar situation have been handled and solved internationally.

The library must pay more attention to organize public lectures, seminars and workshops by inviting scholars and experts on understanding of ethnic crisis, the basis of political solution, basic human rights, concept and principle of negotiation for the conflict, Federalism, decentralization, devolution and can organize community projects, cultural activities, leisure time activities, cultural shows, tours with involvement and integration of all communities.

The library committee should be representative all ethnic groups of the area and the staff should work broadminded with no discrimination based on ethnicity, race or religion. Most public libraries come under purview of the Ministry of Local Government. Therefore the ministry should provide a general work plan for the public libraries to work towards the peace and ethnic harmony in Sri Lanka.

\section{University libraries}

University libraries provide reference service to the more educated population of the country. Thus they could approach its customers in academic ways such as:

Collection and maintenance of research findings, research publication, articles and reference information and data, necessary for research on ethnic conflict, peace and negotiation processes, nationally and internationally, University libraries can also exhibit materials on conflicts, and peace negotiation process in Sri Lanka and other countries, the suggestion for the solution of the present conflict, and ways and means 
of peace processes that solved the conflict in other countries and thus its suitability for the Sri Lanka situation.

The University librarians can compile bibliographies on conflict, peace and negotiation processes. They can provide current awareness services on these subjects. University should pay more concern to conflict and the peace process in its annual publications. Library signboards should be in the common language - English. Presently, students of all communities enter the universities. Therefore, if the library intends to provide good service to the readers, the library staff should have ability to work with all communities. The University of Peradeniya has set a good example there is a Tamil Division and some Tamil speaking library assistants also working at the counter, to augment the English and Sinhalese Language users and resources.

\section{National Library}

The nation library is the central organization to lead, guide, and develop a country's library and information services on all matters relating to conflict solution. The national library must encourage and provide financial help to writers to publish on conflict, peace and ethnic harmony. It must collect publications on their concerns and disseminate these materials among the country's libraries and should encourage translation of books on religious, cultural activities, festivals and materials on conflict and peace. The library must cater to all ethnic groups equally. The national library must train library staffs in the country according to mentioned principles of justice, equity and harmony.

As a result of the above-mentioned activities, libraries can build up mutual understanding among the conflicting parties, by providing 
necessary information of the actual facts behind the conflict and may encourage and motivate the mass media and the public in active participation in the peace process by providing amicable and acceptable resolution for the ethnic conflict. Public participation in debate on the peace negotiation process will help the resumption of the peace process ending fruitfully. The general public is a stakeholder in the peace process. This requires effective mobilization of people for broad based peace movements. With public mobilization, there must be building up of civil society. The library must make the effort, to work with other intellectuals and scholars in formulating a resolution in sustainable manner and to build up sustaining public support for the formulated solution in particular and the peace negotiation process in general. However, it is beyond doubt that the provision of common basic needs to all citizens in the state a role to play a role in fostering civil society in a peaceful ri Lanka.

\section{Conclusion}

The Sri Lankan peace process is at crossroad. The present situation offers a unique opportunity to develop an innovative strategic framework of multiple peace negotiation and peace building. It should be ensured that all the people become co-winners of the process. That the talks are to be based on the concept of principles of negotiation and concrete steps are taken to work jointly on a comprehensive programme of reforming and restructuring the Sri Lankan State as a multinational, multilingual State, Attitudinal changes in the minds of the nations needed to be brought about. The state should develop more effective and innovative communication system strategies for building consensus on the benefits of peace. Public participation as a stakeholder to the peace process should underpin the negotiation process. It requires effective 
mobilization of the people for broad based peace movement. Lastly, by all these way, the nation should compose a civil society. There should be great effort to build a civil society. The library can effectively create a civil society with sustaining public support the will formulate the ways and means towards the ethnic harmony through reference service.

\section{References:}

"Building Local capacities for peace rethinking conflict and development in Sri Lanka" (2003) ed. by Markus Mayer, Darini Rajasinham, Senanayake,Yuvi Thangarajah, New Delhi: Mac Millian India Ltd

"Jaffna Public Library - A Historical compilation".(2001) - Compiler: N.Selvarajah, Auothy Library Services, UK,

"Pursuit of Peace in Sri Lanka Past failures and future prospects". (2000.) ed. by K.M.de Silva and G.H.Peiris, Colombo: International Centre for Ethnic Studies (ICES)

"Encyclopedia Britannicd". (1973). Vol. 13. London: William Benton Publisher, pages 1031-1061

Kumar, Krishan (1978). "Reference services". Fourth Revised Edition. New Delhi: Vikas Publishing House

Piyadasa T.G (1985). "Libraries in Sri Lanka". Delhi: Sri Satguru Publications,

The Oxford English Dictionary (1986) Oxford: Oxford University Press

Weerasinghe, W.K.M.M.K., (2001.). "History of Libraries", Outter, 